\title{
EVALUASI TINGKAT KESEHATAN KEUANGAN BANK STUDI KASUS PADA BPRS XYZ
}

\author{
Hartiwi Prabowo; Mohamad Azhar \\ Jurusan Manajemen, School of Business, Universitas Bina Nusantara \\ Jln. K.H. Syahdan No. 9, Palmerah, Jakarta Barat 11480 \\ Hartiwi2200@binus.ac.id
}

\begin{abstract}
The impact of the financial crisis started from the US hits other countries, and expands into a global economic crisis that has been felt since the second semester of 2008. In the midst of the development which has deterioted and the declining of the public trust in national banking system, banks with Shariah principles become an alternative to the public in obtaining banking services. The research objective is to determine the level of health, funding development, and financing development of BPRS XYZ, before and after the economic crisis in Indonesia. The data collecting technique is secondary data (2006-2009 performance report). Analytical technique used to assess the health of a bank is CAMEL analysis focusing on Capital, Assets, Management, Earning, and Liquidity. From the analysis, it is concluded that BPRS XYZ has improved in health, though in a small percentage. Nevertheless, after the crisis in 2008-2009, it decreased in the ratio of health and increased slightly at the end of 2009. In terms of funding before and after the crisis, BPRS XYZ increased in funds because of the public trust in the transition from conventional banks to Shariah banks. From the financing side, BPRS XYZ developed a very significant financial from 2006 to 2009. Yet, it had not able to meet all the financial requests, due to limited funding.
\end{abstract}

Keywords: health level, monetary, bank

\begin{abstract}
ABSTRAK
Imbas dari krisis keuangan yang berawal dari Amerika Serikat menerpa negara-negara lainnya, dan meluas menjadi krisis ekonomi secara global yang dirasakan sejak semester kedua tahun 2008. Di tengah situasi pembangunan yang memburuk dan semakin menurunnya kepercayaan masyarakat terhadap perbankan nasional, perbankan dengan prinsip Syariah menjadi alternatif masyarakat dalam memperoleh layanan jasa perbankan. Tujuan penelitian adalah untuk mengetahui tingkat kesehatan, perkembangan funding, dan perkembangan financing BPRS XYZ sebelum dan sesudah krisis ekonomi Indonesia. Teknik pengumpulan data dengan data sekunder (Laporan kinerja periode 2006-2009). Teknik analisis yang digunakan untuk menilai kesehatan suatu bank adalah analisis CAMEL yang memfokuskan penilaiannya pada Capital, Assets, Management, Earning, dan Likuidity. Dari hasil analisis disimpulkan bahwa Tingkat Kesehatan BPRS XYZ sebelum krisis ekonomi Indonesia mengalami peningkatan kesehatan, walaupun persentasenya kecil, namun setelah krisis tahun 2008-2009 mengalami penurunan rasio kesehatan dan mengalami peningkatan sedikit di akhir 2009. Dari segi funding sebelum dan setelah krisis mengalami peningkatan penghimpunan dana, karena adanya peralihan kepercayaan masyarakat dari bank konvensional ke bank Syariah. Dari sisi financing BPRS XYZ mengalami perkembangan pembiayaan yang sangat signifikan dari tahun 2006-2009, namun belum mampu memenuhi semua permintaaan pembiayaan, karena dana yang terbatas.
\end{abstract}

Kata kunci: tingkat kesehatan, keuangan, bank 


\section{PENDAHULUAN}

Perbankan memiliki peranan yang sangat strategis dalam menunjang berjalannya roda perekonomian dan pembangunan nasional mengingat fungsinya sebagai lembaga intermediari, penyelenggaraan transaksi pembayaran, serta alat tranmisi kebijakan moneter. Sebagai sebuah negara yang perekonomiannya terbuka, Indonesia tidak luput dari dinamika pasar keuangan global. Termasuk pula imbas dari krisis keuangan yang berawal dari Amerika Serikat, yang menerpa negara-negara lainnya, dan meluas menjadi krisis ekonomi secara global yang dirasakan sejak semester kedua tahun 2008.

Salah satu faktor yang harus diperhatikan oleh bank untuk bisa terus bertahan hidup adalah kinerja (kondisi keuangan) bank atau tingkat kesehatan bank itu sendiri. Kesehatan suatu bank merupakan kepentingan semua pihak yang terkait baik pemilik dan pengelola bank, masyarakat pengguna jasa bank, maupun Bank Indonesia sebagai pembina dan pengawas bank-bank. Bank yang sehat akan mempengaruhi sistem perekonomian suatu negara secara menyeluruh. Penilaian kesehatan bank itu sendiri didasarkan pada perhitungan kuantitatif sesuai dengan prinsip-prinsip perhitungan menurut BIS (Bank for Internasional Settlement). Dengan mengacu pada prinsip-prinsip yang juga ditetapkan di negara lain apabila terdapat faktor-faktor yang berpengaruh terhadap keadaan permodalan bank, disamping perhitungan kuantitatif tersebut, perlu pula dilakukan judgement, baik oleh bank yang bersangkutan maupun oleh Bank Indonesia. Perhitungan kuantitatif memerlukan indikator-indikator yang berupa rasio-rasio atau perbandingan yang ada dalam laporan neraca dan laporan Rugi-Laba yang bersangkutan. Adapun indikator-indikator tersebut diatas meliputi; Analisis Rasio Capital Adequecy, Assets Quality, Management of Risk, Earning Ability, Liquidity Sufficiency. Kesemua analisis rasio tersebut dikenal dengan nama CAMEL Rating System.

BPRS XYZ berdiri pada tahun 2005. Pada saat kondisi bank baru berdiri, BPRS XYZ dihadapkan pada kondisi keuangan global yang memburuk pada penghujung tahun 2008 yang berimbas pada kondisi keuangan Indonesia. Kondisi keuangan Indonesia yang memburuk ini tentu saja berdampak pada semua aktivitas investasi, termasuk juga aktivitas di industri perbankan. Bank BPRS XYZ mengalami penurunan aktivitas funding dan financing mulai tahun 2008-2009. Apakah dengan penurunan aktivitas bank BPRS XYZ akan mengalami likuiditas? Tujuan penelitian adalah untuk mengevaluasi tingkat kesehatan, perkembangan funding, dan perkembangan financing BPRS XYZ sebelum dan sesudah krisis ekonomi Indonesia periode 2006-2008

Peraturan Bank Indonesia nomor: 9/17/PBI/2007 tentang Sistem Penilaian Tingkat Kesehatan Bank Pembiayaan Rakyat berdasarkan Prinsip Syariah, dilakukan dengan memperhitungkan faktor CAMEL melalui dengan pendekatan kuantitatif dan atau kualitatif atas berbagai aspek yang berpengaruh atas kondisi atau kinerja bank dengan melakukan penilaian terhadap faktor financial dan faktor manajemen.

Penilaian kesehatan bank pembiayaan rakyat berdasarkan prinsip syariah mencakup beberapa faktor, yaitu faktor permodalan, rasio kualitas aset, rasio manajemen, aspek rentabilitas, faktor likuiditas.

\section{Faktor Permodalan (capital)}

Penilaian permodalan dimaksudkan untuk menilai kecukupan modal bank dalam mengamankan risiko posisi dan mengantisipasi risiko yang akan muncul. Rasio ini memberikan informasi mengenai apakah modal bank cukup untuk mendukung operasional yang terjadi dalam melakukan penanaman dana atau akibat penurunan aktiva. Adapun rasionya seperti pada Tabel 1. 
Tabel 1 Faktor permodalan

\begin{tabular}{|c|c|c|c|}
\hline & KOMPONEN & FORMULA/RASIO & KETERANGAN \\
\hline & $\begin{array}{l}\text { Rasio Proyeksi } \\
\text { Kecukupan Modal } \\
\text { (Rasio Penunjang) }\end{array}$ & 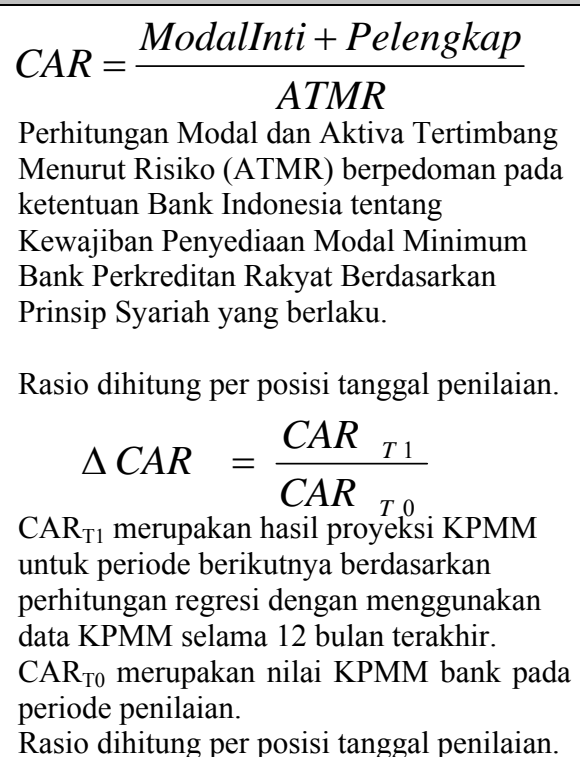 & $\begin{array}{l}\text { Tujuan : Mengukur kecukupan modal bank } \\
\text { dalam menyerap kerugian dan pemenuhan } \\
\text { ketentuan KPMM yang berlaku. } \\
\text { Semakin tinggi rasio ini menunjukkan bahwa } \\
\text { bank semakin solvable. } \\
\text { Kriteria penilaian peringkat: } \\
\text { Peringkat } 1: \text { CAR } \geq 11 \% \\
\text { Peringkat } 2: 9,5 \% \leq \mathrm{CAR}<11 \% \\
\text { Peringkat } 3: 8 \% \leq \mathrm{CAR}<9,5 \% \\
\text { Peringkat } 4: 6,5 \% \leq \mathrm{CAR}<8 \% \\
\text { Peringkat } 5: \text { CAR }<6,5 \% \\
\text { Tujuan : Menilai kecukupan modal dalam } \\
\text { menyerap risiko penempatan dana di masa } \\
\text { datang, melalui proyeksi pertumbuhan CAR. } \\
\text { Kriteria penilaian peringkat: } \\
\text { Peringkat } 1: \Delta \mathrm{CAR} \geq 1,2 \\
\text { Peringkat } 2: 1,1 \leq \Delta \mathrm{CAR}<1,2 \\
\text { Peringkat } 3: 1 \leq \Delta \mathrm{CAR}<1,1 \\
\text { Peringkat } 4: 0,9 \leq \Delta \mathrm{CAR}<1 \\
\text { Peringkat } 5: \Delta \mathrm{CAR}<0,9\end{array}$ \\
\hline & $\begin{array}{l}\text { Rasio kecukupan modal } \\
\text { inti terhadap dana pihak } \\
\text { ketiga (EDR) } \\
\text { (Rasio Observed) }\end{array}$ & $\begin{array}{l}\quad E D R \quad=\frac{M \text { Tier } 1}{D P K g} \\
\text { Perhitungan } \mathrm{M}_{\text {tier 1 }} \text { berpedoman pada } \\
\text { ketentuan Bank Indonesia tentang } \\
\text { Kewajiban Penyediaan Modal Minimum } \\
\text { Bank Perkreditan Rakyat Berdasarkan } \\
\text { Prinsip Syariah yang berlaku. } \\
\text { DPK merupakan DPK non profit sharing } \\
\text { yang dijamin oleh Bank namun tidak } \\
\text { dijamin oleh LPS. } \\
\text { Rasio dihitung per posisi tanggal penilaian. }\end{array}$ & $\begin{array}{l}\text { Tujuan : } \\
\text { Mengukur kemampuan modal inti menutup } \\
\text { kewajiban kepada pemilik dana pihak ketiga } \\
\text { serta memperkirakan potensi biaya sistemik. } \\
\text { Kriteria penilaian peringkat: } \\
\text { Peringkat } 1: \text { EDR } \geq 2 \\
\text { Peringkat } 2 ; 1,5 \leq \mathrm{EDR}<2 \\
\text { Peringkat } 3: 1 \leq \mathrm{EDR}<1,5 \\
\text { Peringkat } 4: 0,5 \leq \mathrm{EDR}<1 \\
\text { Peringkat } 5: \mathrm{EDR}<0,5\end{array}$ \\
\hline 4 & $\begin{array}{l}\text { Fungsi Intermediasi atas } \\
\text { dana investasi dengan } \\
\text { metode Profit Sharing } \\
\text { (FI) } \\
\text { (Rasio Observed) }\end{array}$ & 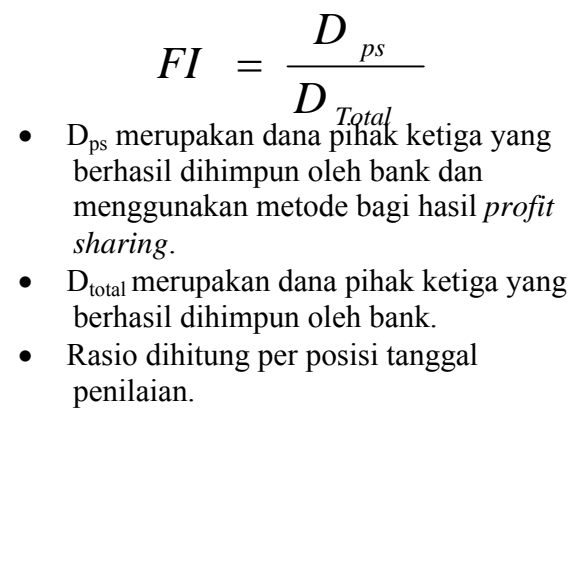 & $\begin{array}{l}\text { Tujuan : } \\
\text { Mengukur proporsi dana profit sharing } \\
\text { terhadap total dana pihak ketiga yang } \\
\text { mencerminkan intensitas fungsi bank sebagai } \\
\text { manajer investasi. } \\
\text { Semakin besar FI akan mempengaruhi } \\
\text { besarnya ATMR dan kebutuhan modal } \\
\text { minimum bank. }\end{array}$ \\
\hline
\end{tabular}

Sumber: Bank Indonesia 


\section{Rasio Kualitas Asset}

Menurut Bank Indonesia (2004) kualitas asset adalah semua aktiva dalam rupiah atau valas yang dimiliki oleh bank dengan maksud untuk memperoleh penghasilan sesuai dengan fungsinya, yaitu pemberian kredit, kepemilikan surat-surat berharga, dan penempatan dana kepada bank lain baik dalam negeri atau luar negeri terkecuali penanaman dana dalam bentuk giro dan penyertaan.

Tabel 2 Faktor Kualitas Asset

\begin{tabular}{|c|c|c|c|}
\hline \multicolumn{4}{|c|}{ MATRIKS PERHITUNGAN/ANALISIS KOMPONEN FAKTOR KUALITAS ASET (ASSET QUALITY) } \\
\hline No & KOMPONEN & FORMULA/RASIO & KETERANGAN \\
\hline 1 & $\begin{array}{l}\text { Rasio Kualitas } \\
\text { Aktiva Produktif } \\
\text { (EAQ) } \\
\text { (Rasio Utama) }\end{array}$ & 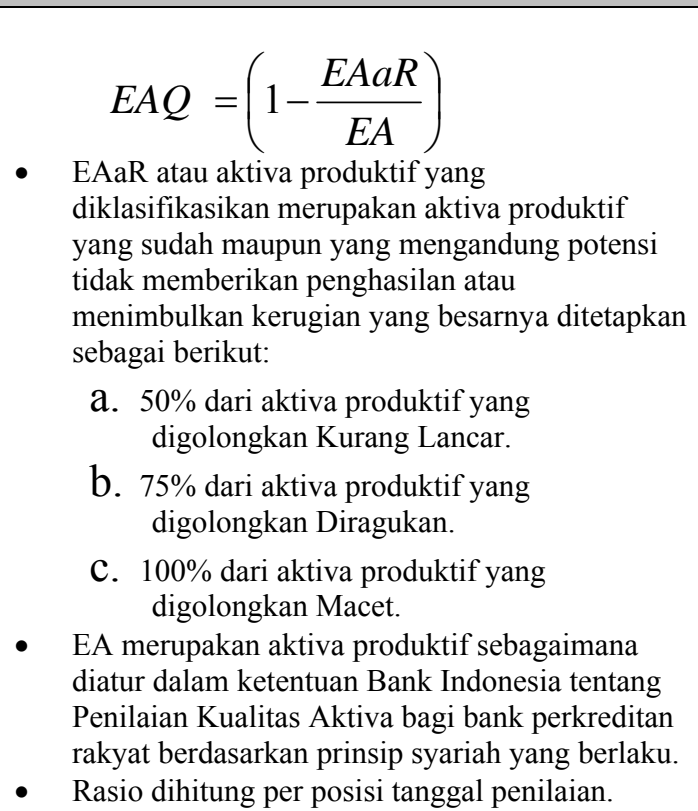 & $\begin{array}{l}\text { Tujuan : } \\
\text { Mengukur proporsi aktiva } \\
\text { produktif yang tidak } \\
\text { diklasifikasikan terhadap total } \\
\text { aktiva produktif. } \\
\text { Kriteria penilaian peringkat: } \\
\text { - } \quad \text { Peringkat } 1 \mathrm{EAQ} \geq 93 \% \\
\text { - } \quad \text { Peringkat } 290 \% \leq \mathrm{EAQ}< \\
\quad 93 \% \\
\text { - } \quad \text { Peringkat } 387 \% \leq \mathrm{EAQ}< \\
\quad 90 \% \\
\text { - } \quad \text { Peringkat } 484 \% \leq \mathrm{EAQ}< \\
\quad 87 \% \\
\text { - } \quad \text { Peringkat } 5 \mathrm{EAQ}<84 \%\end{array}$ \\
\hline 2 & $\begin{array}{l}\text { Rasio pembiayaan } \\
\text { bermasalah (NPF) } \\
\text { (Rasio Penunjang) }\end{array}$ & $\begin{array}{l}\quad N P F=\frac{J P B}{J P} \\
\text { - JPB merupakan jumlah pembiayaan yang } \\
\text { tergolong dalam kolektibilitas Kurang Lancar, } \\
\text { Diragukan dan Macet sesuai dengan ketentuan } \\
\text { Bank Indonesia tentang Penilaian Kualitas } \\
\text { Aktiva Bank Perkreditan Rakyat Berdasarkan } \\
\text { Prinsip Syariah yang berlaku. } \\
\text { JP merupakan jumlah pembiayaan yang dimiliki } \\
\text { oleh bank. } \\
\text { Rasio dihitung per posisi tanggal penilaian. }\end{array}$ & 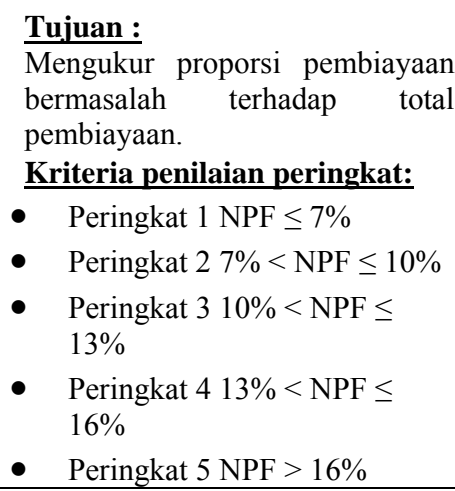 \\
\hline
\end{tabular}

Sumber: Bank Indonesia

\section{Rasio Manajemen}

Menurut Kasmir (2002), rasio manajemen bertujuan untuk mengetahui kinerja manajemen dalam menggunakan semua asset secara efisien. Penilaian terhadap faktor manajemen dilakukan melalui penilaian kepada manajemen permodalan, manajemen aktiva, manajemen rentabilitas, manajemen likuiditas, manajemen umum. Menurut Bank Indonesia (2007) penilaian manajemen dimaksudkan untuk menilai kemampuan manajerial pengurus bank dalam menjalankan usaha sesuai 
dengan prinsip manajemen umum, kecukupan manajemen risiko dan kepatuhan bank terhadap ketentuan baik nyang terkait dengan prinsip kehati-hatian maupun kepatuhan terhadap prinsip syariah dan komitmen bank kepada Bank Indonesia. Penilaian kualitatif faktor manajemen dilakukan dengan penilaian terhadap komponen-komponen Manajemen Umum, Manajemen Risiko dan Manajemen Kepatuhan Syariah

\section{Aspek Rentabilitas (Earning)}

Rasio ini digunakan untuk mengukur efektifitas untuk memperoleh laba. Teknik analisis ini melibatkan hubungan antara pos-pos tertentu dalam perhitungan laba atau rugi untuk memperoleh ukuran-ukuran yang dapat digunakan sebagai indikator untuk menilai efisiensi dan kemampuan memperoleh laba. Untuk menganalisisnya digunakan rumus seperti pada Tabel 3.

Tabel 3 Faktor Rentabilitas

\begin{tabular}{|c|c|c|c|}
\hline \multicolumn{4}{|c|}{ MATRIKS PERHITUNGAN/ANALISIS KOMPONEN FAKTOR RENTABILITAS (EARNING) } \\
\hline No & KOMPONEN & FORMULA/RASIO & KETERANGAN \\
\hline \multirow[t]{2}{*}{1} & \multirow[t]{2}{*}{$\begin{array}{l}\text { Rasio Efisiensi } \\
\text { Operasional (REO) } \\
\text { (Rasio Utama) }\end{array}$} & \multirow{2}{*}{$\begin{array}{l}\qquad R E O=\frac{B O}{P O} \\
\text { - BO atau Beban Operasional merupakan beban } \\
\text { yang dikeluarkan oleh bank untuk membiayai } \\
\text { operasional bank, tidak termasuk bagi hasil } \\
\text { kepada dana pihak ketiga. } \\
\text { - PO atau Pendapatan Operasional merupakan } \\
\text { pendapatan yang diterima oleh bank setelah } \\
\text { dikurangi dengan bagi hasil kepada dana pihak } \\
\text { ketiga. } \\
\text { - Rasio dihitung per posisi tanggal penilaian. }\end{array}$} & $\begin{array}{l}\text { Tujuan : } \\
\text { Mengukur efisiensi operasi BPRS. }\end{array}$ \\
\hline & & & $\begin{array}{l}\text { Kriteria penilaian peringkat: } \\
\text { - } \text { Peringkat } 1 \mathrm{REO} \leq 83 \% \\
\text { - } \text { Peringkat } 283 \%<\mathrm{REO} \leq 85 \% \\
\text { - } \text { Peringkat } 385 \%<\mathrm{REO} \leq 87 \% \\
\text { - } \text { Peringkat } 487 \%<\mathrm{REO} \leq 89 \% \\
\text { - } \text { Peringkat } 5 \mathrm{REO}>89 \%\end{array}$ \\
\hline \multirow[t]{2}{*}{2} & \multirow[t]{2}{*}{$\begin{array}{l}\text { Rasio aset yang } \\
\text { menghasilkan } \\
\text { pendapatan (IGA) } \\
\text { (Rasio Penunjang) }\end{array}$} & \multirow{2}{*}{$\begin{array}{l}\quad I G A=\frac{(A P-N P A)}{T A} \\
\text { - AP atau Aktiva Produktif sebagaimana dimaksud } \\
\text { dalam ketentuan Bank Indonesia tentang } \\
\text { Penilaian Kualitas Aktiva bagi bank perkreditan } \\
\text { rakyat berdasarkan prinsip syariah yang berlaku. } \\
\text { - NPA atau Non Performing Asset adalah Aktiva } \\
\text { Produktif yang tergolong Kurang Lancar, } \\
\text { Diragukan dan Macet sebagaimana dimaksud } \\
\text { dalam ketentuan Bank Indonesia tentang } \\
\text { Penilaian Kualitas Aktiva bagi bank perkreditan } \\
\text { rakyat berdasarkan prinsip syariah yang berlaku. } \\
\text { - TA adalah Total Asset yang dimiliki oleh bank, } \\
\text { yang dihitung berdasarkan data selama } 12 \text { bulan } \\
\text { terakhir dari bulan laporan. } \\
\text { - Rasio dihitung per posisi tanggal penilaian. }\end{array}$} & $\begin{array}{l}\text { Tujuan : } \\
\text { Mengukur proporsi aset yang } \\
\text { memberikan pendapatan, terhadap } \\
\text { total aset. }\end{array}$ \\
\hline & & & 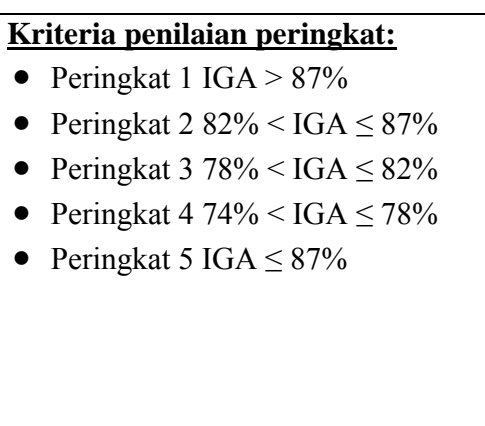 \\
\hline 3 & $\begin{array}{l}\text { Rasio Net Margin } \\
\text { Operasional utama } \\
\text { (NSOM) } \\
\text { (Rasio Penunjang) }\end{array}$ & $N S O M=\frac{P O u-B H-B O u}{A P}$ & $\begin{array}{l}\text { Tujuan : } \\
\text { Mengukur proporsi pendapatan bersih } \\
\text { utama setelah dikurangi distribusi } \\
\text { bagi hasil dan biaya operasi utama, } \\
\text { terhadap aktiva produktif. }\end{array}$ \\
\hline
\end{tabular}




\begin{tabular}{|c|c|c|c|}
\hline & & $\begin{array}{l}\text { - POu atau Pendapatan Operasional Utama adalah } \\
\text { pendapatan yang diterima oleh bank dari } \\
\text { aktivitas penyaluran dana. } \\
\text { - BH atau Bagi Hasil adalah distribusi bagi hasil } \\
\text { yang dilakukan bank atas dana mudharabah yang } \\
\text { diterima oleh bank. } \\
\text { - BOu atau Beban Operasional Utama adalah } \\
\text { beban yang dikeluarkan oleh bank untuk } \\
\text { membiayai aktivitas utama bank. } \\
\text { - AP dihitung berdasarkan data selama } 12 \text { bulan } \\
\text { terakhir dari bulan laporan } \\
\text { - Rasio dihitung per posisi tanggal penilaian. }\end{array}$ & $\begin{array}{ll}\text { Kriteria penilaian peringkat: } \\
\text { - } & \text { Peringkat } 1 \mathrm{NSOM} \geq 9 \% \\
\text { - } & \text { Peringkat } 27 \% \leq \mathrm{NSOM}<9 \% \\
\text { - } & \text { Peringkat } 35 \% \leq \mathrm{NSOM}<7 \% \\
\text { - } & \text { Peringkat } 43 \% \leq \mathrm{NSOM}<5 \% \\
\text { - } & \text { Peringkat } 5 \mathrm{NSOM} \leq 3 \%\end{array}$ \\
\hline \multirow[t]{2}{*}{4} & \multirow[t]{2}{*}{$\begin{array}{l}\text { Return on Assets } \\
\text { (ROA) } \\
\text { (Rasio Observed) }\end{array}$} & \multirow[b]{2}{*}{$\begin{array}{l}\text { - EBT atau Earning Before Tax adalah laba yang } \\
\text { diperoleh oleh bank sebelum perhitungan pajak } \\
\text { dan telah memperhitungkan kekurangan PPA. } \\
\text { - EBT diperoleh dari akumulasi laba sebelum } \\
\text { pajak dalam } 12 \text { bulan terakhir dari bulan laporan. } \\
\text { - TA adalah Total Asset yang dimiliki oleh bank. } \\
\text { - Rasio dihitung per posisi tanggal penilaian. }\end{array}$} & $\begin{array}{l}\text { Tujuan: } \\
\text { Mengukur tingkat kemampulabaan } \\
\text { bank atas aset yang dimiliki. }\end{array}$ \\
\hline & & & $\begin{array}{ll}\text { Kriteria penilaian peringkat: } \\
\text { - } & \text { Peringkat } 1 \mathrm{ROA}>1,450 \% \\
\text { - } & \text { Peringkat } 21,215 \%<\mathrm{ROA} \leq \\
& 1,450 \% \\
\text { - } & \text { Peringkat } 30,999 \%<\mathrm{ROA} \leq \\
& 1,215 \% \\
\text { - } & \text { Peringkat } 40,765 \%<\mathrm{ROA} \leq \\
& 0,999 \% \\
\text { - } & \text { Peringkat } 5 \mathrm{ROA} \leq 0,765 \%\end{array}$ \\
\hline \multirow[t]{2}{*}{5} & \multirow[t]{2}{*}{$\begin{array}{l}\text { Return On Equity } \\
\text { (ROE) } \\
\text { (Rasio Observed) }\end{array}$} & \multirow{2}{*}{$\begin{array}{l}\qquad R O E=\frac{E A T}{P I C} \\
\text { - EAT atau Earning After Tax adalah laba yang } \\
\text { diperoleh oleh bank setelah perhitungan pajak } \\
\text { dan telah memperhitungkan kekurangan PPA. } \\
\text { - EAT diperoleh dari akumulasi laba setelah pajak } \\
\text { dalam } 12 \text { bulan terakhir dari bulan laporan. } \\
\text { - PIC atau Paid In Capital adalah modal disetor } \\
\text { yang dimiliki oleh bank. } \\
\text { PIC dihitung berdasarkan data rata-rata selama } \\
\text { 12 bulan terakhir dari bulan laporan. } \\
\text { - Rasio dihitung per posisi tanggal penilaian. }\end{array}$} & $\begin{array}{l}\text { Tujuan : } \\
\text { Mengukur tingkat kemampulabaan } \\
\text { bank atas modal yang dimiliki. }\end{array}$ \\
\hline & & & $\begin{array}{ll}\text { Kriteria penilaian peringkat: } \\
\text { - } & \text { Peringkat } 1 \mathrm{ROE}>23 \% \\
\text { - } & \text { Peringkat } 218 \%<\mathrm{ROE} \leq 23 \% \\
\text { - } & \text { Peringkat } 313 \%<\mathrm{ROE} \leq 18 \% \\
\text { - } & \text { Peringkat } 48 \%<\mathrm{ROE} \leq 13 \% \\
\text { - } & \text { Peringkat } 5 \mathrm{ROE} \leq 8 \%\end{array}$ \\
\hline
\end{tabular}

\section{Rasio Likuiditas}

Rasio ini digunakan sebagai perkiraan terhadap penarikan dana oleh deposan dan permintaan pembiayaan yang telah disetujui oleh Bank. Oleh karena itu, rasio ini merupakan teknik untuk mengukur kemampuan Bank dalam memenuhi kebutuhan likuiditas yang segera harus dibayar dan dipenuhi. 
Tabel 4 Faktor Liquiditas

\begin{tabular}{|c|c|c|c|}
\hline \multicolumn{4}{|c|}{ MATRIKS PERHITUNGAN/ANALISIS KOMPONEN FAKTOR LIKUIDITAS (LIQUIDITY) } \\
\hline No & KOMPONEN & FORMULA/RASIO & KETERANGAN \\
\hline \multirow[t]{3}{*}{1} & \multirow{3}{*}{$\begin{array}{l}\text { Cash Ratio (CR) } \\
\text { (Rasio Utama) }\end{array}$} & Cash \& SetaraKas & \multirow{2}{*}{$\begin{array}{l}\text { Tujuan : } \\
\text { Mengukur kemampuan alat likuid bank } \\
\text { dalam memenuhi kebutuhan likuiditas } \\
\text { jangka pendek (sampai dengan } 1 \\
\text { bulan). }\end{array}$} \\
\hline & & $\mathrm{CK}=\overline{\text { Kewajiban_Lancar }}$ & \\
\hline & & $\begin{array}{l}\text { Cash \& Setara Kas adalah kas, giro dan } \\
\text { tabungan pada bank lain. } \\
\text { Kewajiban Lancar meliputi tabungan, } \\
\text { deposito, kewajiban kepada bank lain, } \\
\text { kewajiban segera dan kewajiban lainnya } \\
\text { yang jatuh tempo sampai dengan } 1 \\
\text { bulan. } \\
\text { Data dalam perhitungan komponen ini } \\
\text { diperoleh dari laporan mingguan yang } \\
\text { dilaporkan BPRS melalui laporan } \\
\text { bulanan BPRS. } \\
\text { Rasio dihitung per posisi tanggal } \\
\text { penilaian. }\end{array}$ & $\begin{array}{ll}\text { Kriteria penilaian peringkat: } \\
\text { - } & \text { Peringkat } 1 \mathrm{CR} \geq 4,80 \% \\
\text { - } & \text { Peringkat } 24,05 \% \leq \mathrm{CR}<4,80 \% \\
\text { - } & \text { Peringkat } 33,30 \% \leq \mathrm{CR}<4,05 \% \\
\text { - } & \text { Peringkat } 42,55 \% \leq \mathrm{CR}<3,30 \% \\
\text { - } & \text { Peringkat } 5 \mathrm{CR}<2,55 \%\end{array}$ \\
\hline
\end{tabular}

Sumber: Bank Indonesia

\section{METODE}

Jenis penelitian yang digunakan adalah penelitian deskriptif, menggunakan teknik pengumpulan data melalui wawancara dengan direktur BPRS XYZ dan data sekunder perusahaan. Metode analisa tingkat kesehatan bank umum berdasarkan Prinsip Syariah. Pemenuhan Prinsip Syariah dilaksanakan dengan memenuhi ketentuan pokok hukum Islam antara lain prinsip keadilan dan keseimbangan ('adl wa tawazun), kemaslahatan (maslahah), dan universalisme (alamiyah) serta tidak mengandung gharar, maysir, riba, zalim dan objek haram

\section{HASIL DAN PEMBAHASAN}

\section{Evaluasi Tingkat Kesehatan Keuangan BPRS XYZ}

Kondisi permodalan pada BPRS XYZ selama tahun 2006-2009 dalam kondisi yang sangat sehat. Ini dapat dilihat pada tabel perhitungan, posisi CAR secara keseluruhan selama 5 tahun berturutturut berada pada posisi di atas standar yang telah menjadi ketetapan BI yaitu 8\%. Dalam kondisi demikian menunjukan bahwa bank memiliki modal yang sangat kuat untuk menutup risiko kerugian dan melakukan hapus buku akibat penurunan kualitas aktiva. Akan tetapi bank harus hati-hati karena rasio CAR terus menurun dari tahun ke tahun (penurunan sebesar 2,04\% dari tahun 2008 ke tahun 2009). Dari segi $\triangle$ CAR tahun 2008 BPRS XYZ terkena imbas dari krisis global karena pengaruh perubahan perekonomian tetapi tahun 2009 sudah ada peningkatan sebesar 0,08\%. BPRS harus menjaga rasio EDRnya karena rasio tersebut terus mengalami penurunan yang mengakibatkan kemampuan modal inti menutup kewajiban kepada pemilik dana pihak ketiga menurun. Rasio FI tahun 2008 menurun karena terkena dampak krisis global akan tetapi tahun 2009 mengalami sudah mengalami peningkatan sebesar 2,38. 


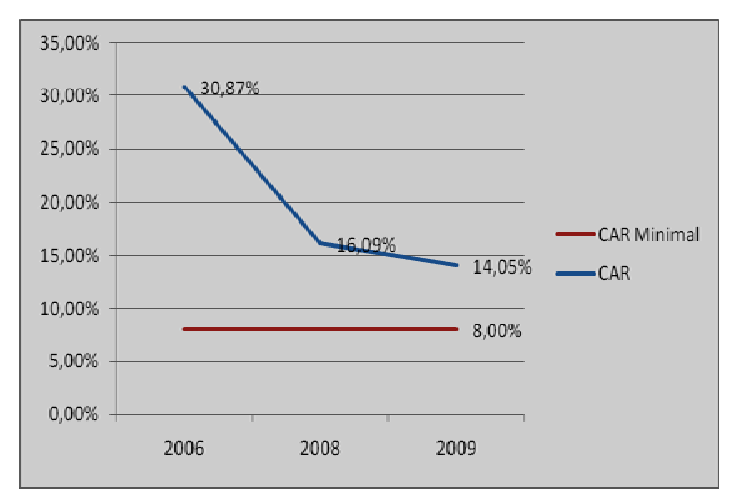

Gambar 1 Grafik CAR

Sumber: Data olahan

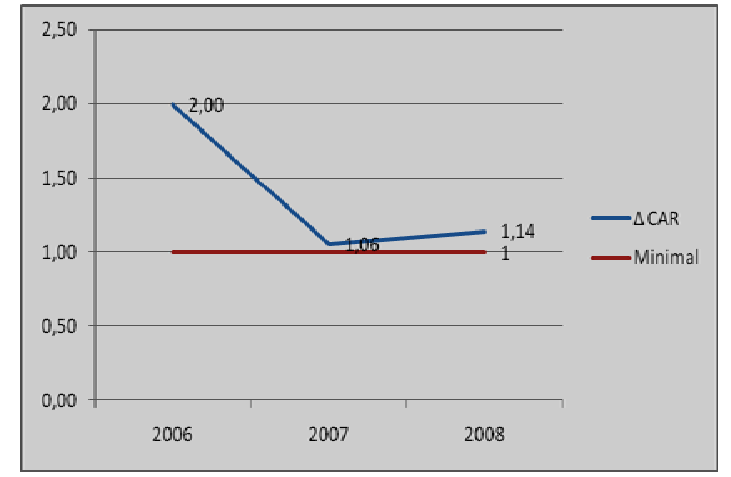

Gambar 2 Grafik $\triangle \mathrm{CAR}$ Sumber: Data olahan

Kondisi kualitas asset BPRS XYZ berada dalam kondisi sehat pada tahun 2006, 2008, dan 2009, karena pososo EAQ berada diatas EAQ minimal yang diisyaratkan yaitu minimal $87 \%$. Berarti BPRS XYZ memiliki aktiva produktif dengan tingkat pengembalian yang sangat tinggi. Meskipun pada tahun 2006-2008 terjadi penurunan sebesar 1,91\% akan tetapi pada tahun 2009 BPRS XYZ mampu meningkatkan EAQnya sebesar 0,29\% menjadi 98,13\%. BPRS XYZ juga dapat menekan rasio NPFnya pada tahun 2009 sebesar $0,66 \%$ menjadi 3,12 walaupun tahun 2008 jumlah NPFnya meningkat menjadi $3,78 \%$ yang berati BPRS XYZ berhasil mengatasi pembiayaan bermasalah dampak dari krisis global 2008.

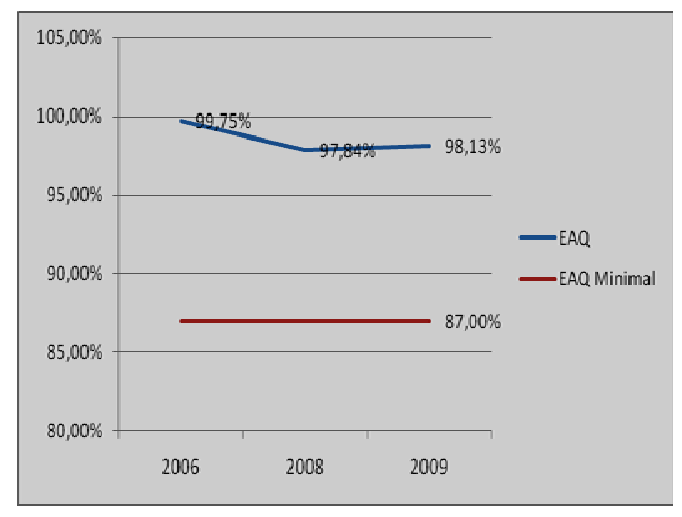

Gambar 3 Grafik EAQ

Sumber: Data olahan

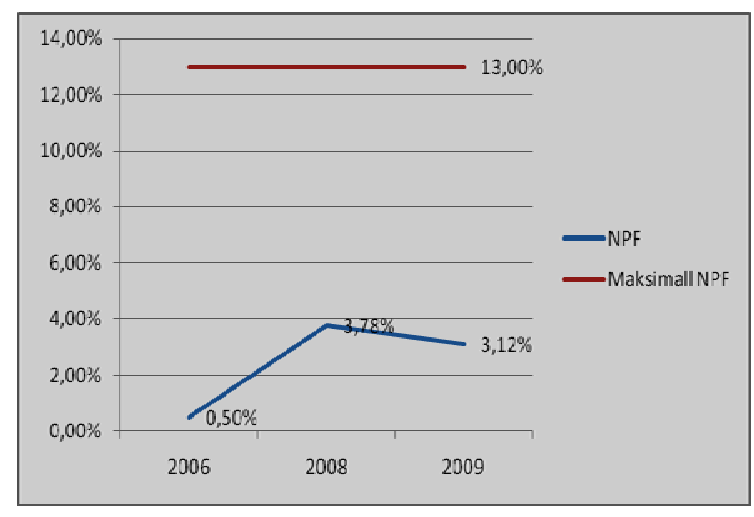

Gambar 4 Grafik NPF

Sumber: Data olahan

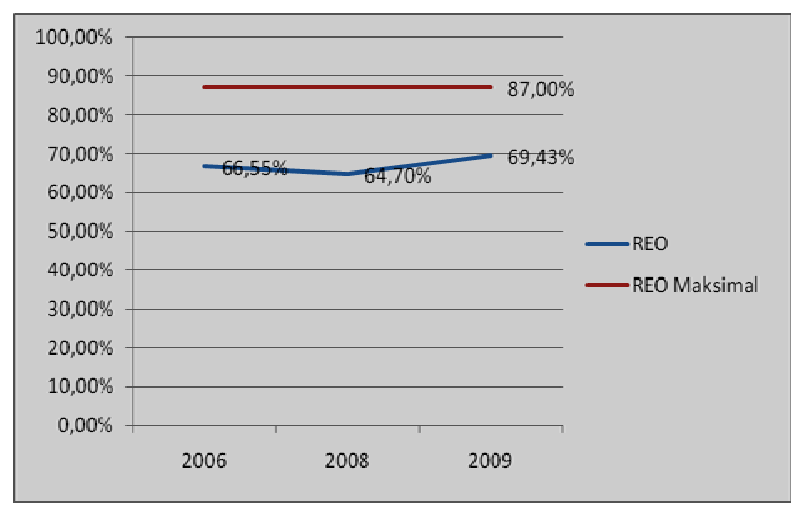

Gambar 5 Grafik REO

Sumber: Data olahan 
Rasio rentabilitas BPRS XYZ mendapatkan peringkat 2 selama tahun 2006, 2008 (lihat kriteria peringkat di Tabel 3 kriteria REO) yang berarti bank memiliki efisiensi yang tinggi dan stabil sehingga memiliki potensi untuk memperoleh keuntungan yang tinggi. Tahun 2009 mendapat peringkat 3 (kriteria REO 85\% < REO $\leq 87 \%$ ), yang berarti bank memiliki efisiensi operasi yang cukup memadai dan stabil sehingga memiliki potensi untuk memperoleh keuntungan yang memadai. Rasio ini dipengaruhi peningkatan rasio REO tahun 2009 sebesar 4,73\% menjadi $69,43 \%$ yang berarti BPRS XYZ berhasil melakukan efisiensi untuk menekan dampak krisis global yang pada tahun 2008 menurun menjadi $64,70 \%$.

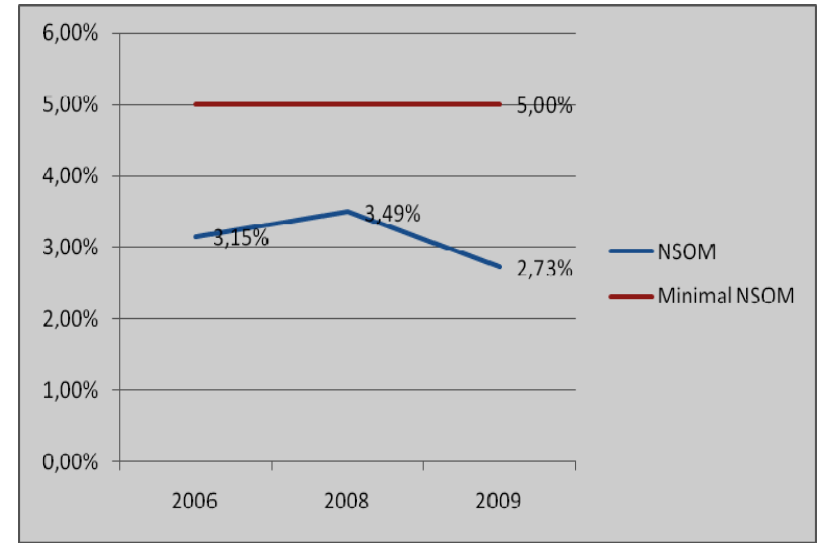

Gambar 6 Rasio rentabilitas BPRS XYZ

Sumber: Data olahan

Akan tetapi BPRS XYZ harus mengawasi penurunan rasio NSOM tahun 2009 sebesar $0,76 \%$ menjadi 2,73\% yang berarti faktor pendapatan bersih utama setelah dikurangi distribusi bagi hasil dan biaya operasi utama menurun, rasio ROA tahun 2009 juga menurun sebesar $0,55 \%$ menjadi 3,63\% yang berarti kemampuan laba terhadap total asset menurun, rasio ROE juga mengalami penurunan sebesar $0,25 \%$ menjadi $17,02 \%$ yang berarti kemampuan laba terhadap modal yang dimiliki menurun.

Dari hasil evaluasi rasio likuiditas $(2006=29,14 \% ; 2008=14,8 \%$ dan tahun $2009=17,91 \%)$ menunjukan BPRS XYZ masih diatas ketetapan Bank Indonesia sebesar 3,30\% yang berarti bank memiliki potensi masalah likuiditas jangka pendek sangat rendah.

\section{Penilaian Peringkat Faktor Manajemen}

Penilaian manajemen dimaksudkan untuk menilai kemampuan manajerial pengurus bank dalam menjalankan usaha sesuai dengan prinsip manajemen umum, kecukupan manajemen risiko dan kepatuhan bank terhadap ketentuan baik yang terkait dengan prinsip kehati-hatian maupun kepatuhan terhadap prinsip syariah dan komitmen bank kepada Bank Indonesia.

\section{Kriteria penilaian peringkat}

Peringkat A Total $\geq 75 \%$, Peringkat B $75 \% \leq$ Total $<50 \%$, Peringkat C $50 \% 0 \leq$ Total $<25 \%$, dan Peringkat D Total $<25 \%$. Hasil Penilaian bank BPRS XYZ pada tahun 2006 sampai dengan 2009 berada pada peringkat $\mathrm{A}$. 
Tabel 5 Peringkat Faktor Manajemen

\begin{tabular}{|c|c|c|c|c|c|}
\hline \multicolumn{6}{|c|}{ Peringkat Faktor Manajemen } \\
\hline No & Aspek-Aspek Penilaian & Bobot & 2006 & 2008 & 2009 \\
\hline 1 & Komponen Manajemen Umum & $35 \%$ & $35,00 \%$ & $35,00 \%$ & $35,00 \%$ \\
\hline 2 & Komponen Manajemen Resiko & $40 \%$ & $38,52 \%$ & $35,56 \%$ & $37,04 \%$ \\
\hline 3 & Komponen Manajemen Kepatuhan Syariah & $25 \%$ & $25,00 \%$ & $25,00 \%$ & $25,00 \%$ \\
\hline \multicolumn{2}{|c|}{ Total } & $100,00 \%$ & $98,52 \%$ & $95,56 \%$ & $97,04 \%$ \\
\hline
\end{tabular}

\section{Perkembangan Funding dan Financing BPRS XYZ}

BPRS XYZ merupakan lembaga keuangan syariah yang berfungsi untuk penghimpunan dana maupun penyaluran dana ke masyarakat berdasarkan prinsip bagi hasil. Untuk fungsi penghimpunan dana masyarakat berbentuk tabungan dan deposito berjangka. Adapun data-data penghimpunan dana selama 5 tahun seperti pada Gambar 7.

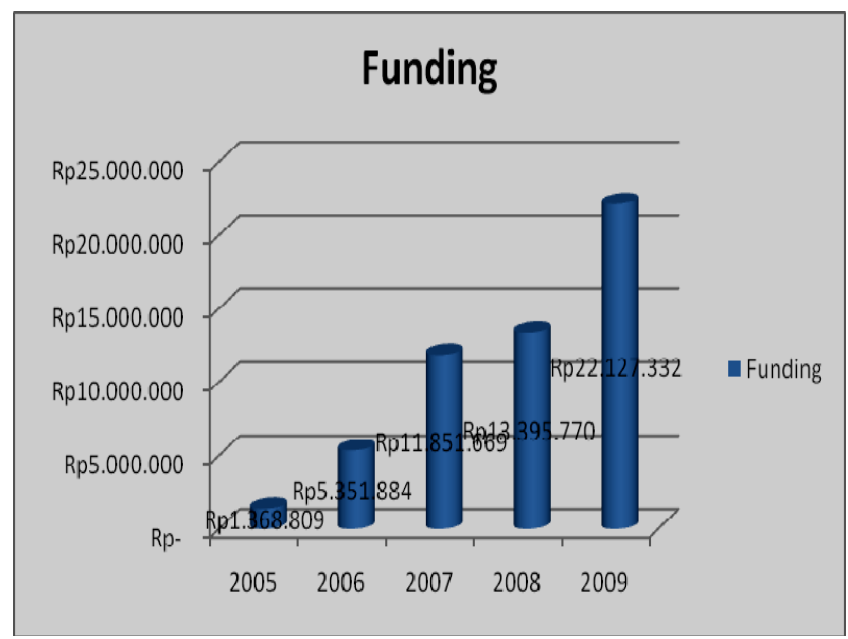

Gambar 7 Perkembangan funding BPRS XYZ

Perkembangan penghimpunan mengalami kenaikan walaupun persentasenya semakin kecil dipengaruh oleh penghimpunan modal bank sendiri dan DPK. Peningkatan yang paling rendah terjadi pada tahun 2008 dikarenakan pengaruh krisis global, akan tetapi pada tahun 2009 ada peningkatan penghimpunan menjadi $65,18 \%$ karena dipengaruhi beralihnya kepercayaan masyarakat untuk menyimpan dananya dari bank konvensional ke bank syariah. Untuk fungsi yang kedua (financing), BPRS XYZ merupakan lembaga keuangan syariah yang mempunyai kegiatan menyalurkan dana yang berasal dari masyarakat untuk kepentingan konsumsi ataupun untuk kepentingan produktif kepada para nasabah. Dari pembiayaan ini BPRS XYZ dapat memperoleh hasil dari pembagian keuntungan. 


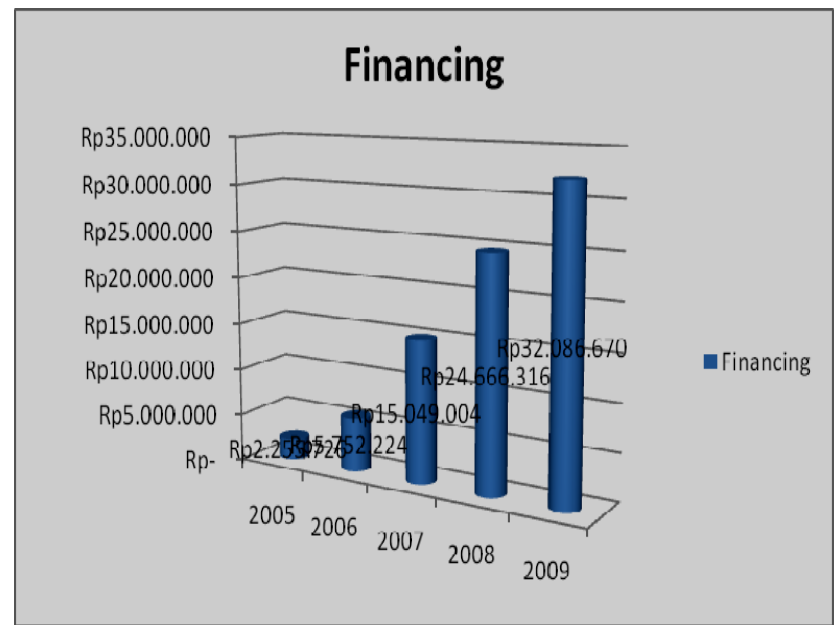

Gambar 8 Perkembangan financing BPRS XYZ

Perkembangan financing dari tahun ke tahun mengalami kenaikan walaupun persentasenya semakin kecil. Faktor ini disebabkan BPRS XYZ tidak mampu memenuhi permintaan pembiayaan karena pengaruh perkembangan penghimpunan dana.

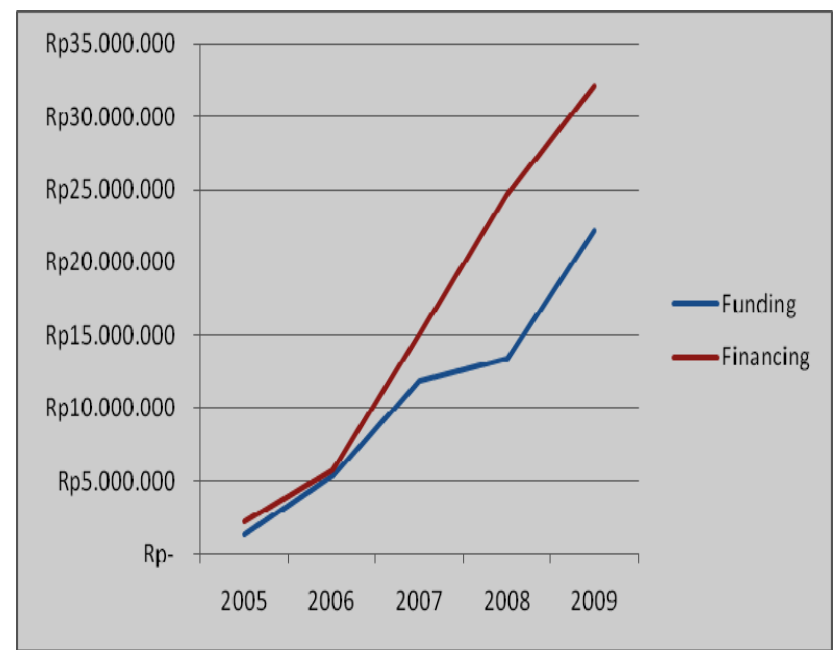

Gambar 9 Perbandingan funding dan financing BPRS XYZ

Dalam perkembangan penghimpunan dan pembiayaan dana pada tahun 2006, 2007, 2008, 2009 BPRS XYZ mengalami penurunan persentasi yang berarti bank tersebut kurang mampu untuk memenuhi pembiayaan, sehingga BPRS XYZ harus lebih giat lagi dalam pembiayaan dananya. Perkembangannya tidak sebanding dengan penghimpunannya (lihat gambar dan tabel dibawah ini) sehingga laba yang dihasilkan bank akan sedikit. Untuk dapat meningkatkan pembiayaan dana antara lain dengan cara menambah produk-produk pembiayaan yang menarik, menyederhanakan prosedur pembiayaan agar kalangan menegah kebawah bisa mengaksesnya, menjalin kerjasama dengan UKM, pedagang pasar, pedagang asongan dan sebagainya. Selain memberikan pembiayaan dana bank juga harus memberikan pembekalan keterampilan dan tata kelolah usaha yang baik. 
Tabel 6 Perbandingan funding dan financing

\begin{tabular}{lrrrrr}
\hline Tahun & $\mathbf{2 0 0 6}$ & $\mathbf{2 0 0 7}$ & $\mathbf{2 0 0 8}$ & $\mathbf{2 0 0 9}$ & Jumlah \\
\hline Financing & $155,01 \%$ & $161,62 \%$ & $63,91 \%$ & $30,08 \%$ & $410,62 \%$ \\
Funding & $290,99 \%$ & $121,45 \%$ & $13,03 \%$ & $65,18 \%$ & $490,65 \%$ \\
Selisih & $-135,98 \%$ & $40,17 \%$ & $50,88 \%$ & $35,10 \%$ & $-80,03 \%$ \\
\hline
\end{tabular}

Sumber Data : Data olahan

\section{SIMPULAN}

Kondisi permodalan pada BPRS XYZ periode 2006-2008 memiliki CAR yang meningkat, akan tetapi bank harus hati-hati karena rasio CAR menurun tahun2008 akhir dan peningkatan ditahun 2009 sangat kecil. Kondisi kualitas asset BPRS XYZ berada dalam kondisi sehat pada tahun 2006, 2008, dan 2009.yang berarti bank memiliki aktiva produktif dengan tingkat pengembalian yang sangat tinggi (diatas kriteria rasio yang ditetapkan). Meskipun pada tahun 2006-2008 terjadi penurunan sebesar 1,91\% akan tetapi pada tahun 2009 mampu meningkatkan EAQ-nya sebesar 0,29\% menjadi 98,13\%. Sejak tahun 2006-2009 BPRS XYZ mampu mengendalikan rasio rentanbilitasnya ke kondisi yang sangat sehat yang berarti bank mempunyai tingkat efisiensi operasi yang sangat tinggi dan stabil sehingga memiliki potensi untuk memperoleh keuntungan yang tinggi. Dari analisa likuiditas menunjukan bahwa CR (Cash Rasio) BPRS masih diatas ketetapan Bank Indonesia sebesar 3,30\% yang berarti bank memiliki potensi masalah likuiditas jangka pendek sangat rendah. Sejak tahun 2008 BPRS ada peningkatan jumlah CR. Manajemen BPRS XYZ mempunyai reputasi yang baik sehingga bank mempunyai tata kelola yang baik, mempunyai ketahanan menghadapi resiko yang kuat, dan kepatuhan pada syariah. Perkembangan funding (penghimpunan dana) dan financing (pembiayaan) selama 5 tahun dapat dilihat pada tabel dimana dari tahun 2005-2009 terus mengalami peningkatan, akan tetapi jumlah pembiayaan tidak sebanding dengan jumlah penghimpunan dana yang dapat menimbulkan ketidakmampuan memenuhi permintaan pembiayaan.

\section{Saran}

BPRS XYZ harus terus menjaga CAR tetap diatas ketentuan yang telah ditetapkan Bank Indonesia karena dari tahun ke tahun jumlah CAR terus menurun. Hal ini bisa dilakukan dengan menambah modal sendiri bank dan DPK dengan cara meningkatkan penghimpunan dana (funding) masyarakat, agar pembiayaan yang bisa dilakukan semakin besar. Untuk meningkatkan pembiayaan BPRS XYZ dapat membuat penawaran produk pembiayaan yang lebih sederhana, tanpa jaminan, dan pembinaan karena sektor perekonomian yang dituju bank adalah kalangan ekonomi menengahkebawah yang kebanyakan tidak mampu memenuhi aspek penilaian kelayakan peminjam. 


\section{DAFTAR PUSTAKA}

Gubernur Bank Indonesia. (2006). PBI No 8/22/PBI/2006 tentang Kewajiban Modal Minimum Bank Perkreditan Rakyat berdasarkan Prinsip Syariah. Lembaran Negara Republik Indonesia Tahun 2006 Nomor 79.

Gubernur Bank Indonesia. (2006). PBI No 8/24/PBI/2006 tentang Penilaian Kualitas Aktiva Bagi Bank Perkreditan Rakyat berdasarkan Prinsip Syariah. Lembaran Negara Republik Indonesia Tahun 2006 Nomor 81.

Gubernur Bank Indonesia. (2007). PBI No. 9/17/PBI/2007 tentang Sistem Penilaian Tingkat Kesehatan Bank Pembiayaan Rakyat berdasarkan Prinsip Syariah. Lembaran Negara Republik Indonesia Tahun 2007 Nomor 146.

Kasmir. (2004). Manajemen perbankan. Jakarta: Raja Grafindo Persada. 